\title{
Loren Barritt
}

Professor of Education at the University of Michigan. In 1985-1986 he spent his third year in the Netherlands, a country he learned to know and admire when he was Fulbright Professor in 1973-1974. He has now returned to Michigan to continue work with students interested in descriptive research. $\mathrm{He}$ is writing a book, $A$ School in Holland, and is beginning a new adventure as Chairperson of the Program in Curriculum, Teaching, and Psychological Studies at the School of Education, University of Michigan, Ann Arbor.

\section{Hans Bleeker and Karel Mulderij}

Both teach at the University of Utrecht and are engaged in phenomenological research into the lifeworld of physically handicapped children. They are the authors of several books about children's experience of place and space. Their most recent books are Pedagogiek op je Knieën (Pedagogy on Your Knees, 1984), a dissertation study on several aspects of qualitative-pedagogical research and, together with Ton Beekman and Loren Barritt, Researching Educational Practice (1985).

\section{Helmut Danner}

Privatdozent of Education at the University of Munich, West Germany; Director of Adult Education, Youth Care, and Social Research Projects in Cairo, Egypt, since October 1986. His writings have dealt mainly with ethical, anthropological, and epistemological foundations of a humanistic education and a hermeneutical and phenomenological theory of education. Books include, Das Göttliche und der Gott bei Heidegger (The Divine and Divinity in Heidegger, 1971); Methoden geisteswissenschaftlicher Pädagogik (Introduction to Hermeneutics, Phenomenology, and Dialectics, 1979); together with Langeveld, Methodologie und "Sinn"-Orientierung in der Pädagogik (Method and Meaning-Orientation to Pedagogy, 1981), Verantwortung und Pädagogik (Responsibility and Education, 1983; 1985 2nd ed.); together with Lippitz (Eds.), Beschreiben-Verstehen-Handeln (Description-UnderstandingAction, 1984); together with others, Zum Menschen erziehen. PestalozziSteiner-Buber (Education Toward Humanness. Pestalozzi-Steiner-Buber, 1985).

\section{Amedeo Giorgi}

Director of Research at Saybrook Institute, San Francisco. His writings have dealt with issues concerning the theory and practice of human scientific research. His latest publication is an edited book, Phenomenology and Psychological Research. He is currently president-elect, Division 32 of the American Psychological Association, division of Humanistic Psychology.

\section{Bas Levering}

Associate Professor of Education at the University of Utrecht. His writings have dealt with the foundations of pedagogy as a practical science with a special interest for ordinary language analysis. He edited Theoretische Pedagogiek (Theory of Pedagogy, 1982, with B. Spiecker and A.J. Beekman) and Over het Bijzondere van de Orthopedagogiek (Orthopedagogy as a Special Discipline, 1986, with J. van Weelden). 


\section{Wilfried Lippitz}

Professor of Education at Universität-Gesamthochschule-Siegen, West

Germany. His writings have dealt with philosophical, special phenomenological foundations of education, with models of teaching and instruction, and with research into the lifeworld of children. Books include, Dialektische

Bildungstheorie in dialektischer Writink (Dialectical Educational Theory in Dialectical Text), Lebenswelt oder die Rehabilitierung vorwissenschaftlicher Erfahrung (The Lifeworld or the Restoration of Pretheoretic Experience), Tasten Gestalten (Sensory Images), Geniessen (Joy), Einführung in Konkretes pädagogisch-anthropologisches Denken (Introduction to Concrete Pedagogical-Anthropological Thinking); together with K. Meyer-Drawe (Ed.), Lernen und seine Horizonte (Learning and its Horizons), Kind und Welt (Child and World); together with H. Danner (Ed.), Beschreiben-VerstehenHandeln (Description-Understanding-Action); together with B. Fichtner and H.-J. Fischer (Eds.), Pädagogik zwischen Geistes-und Sozialwissenschaft (Pedagogy Between Human and Social Science).

\section{Werner Loch}

Professor of Education at the Institute for Pedagogy, University of Kiel, Federal Republic of Germany. His fields of research and writing are pedagogical anthropology, history and theory of education, moral questions of educational professions. The methodological position is characterized by a combination of hermeneutics and phenomenology. Most of his recent writings are concerned with the biographical perspective in educational theory, especially developmental stages of education, the problems of self-realization by learning in the adolescent, and educational competence in the adult.

\section{Käte Meyer-Drawe}

Professor of Historical and Systematic Pedagogy at the Institute of Pedagogy, Ruhr-Universität Bochum, Western Germany. Her writings deal with problems of theories of learning, especially learning of mathematics, and questions of incorporating social structures. Her special interest is in French phenomenology and critical social theory of development of children. Her most recent book is, Leiblichkeit und Sozialität. Phänomenologische Beiträge zu einer pädagogischen Theorie der Inter-Subjektivität (Embodiment and Sociality. Phenomenological Contributions to a Pedagogical Theory of Intersubjectivity, 1984).

\section{Valerie Polakow}

Assistant Professor, University of Michigan, Ann Arbor. Her writings include The Erosion of Childhood (1982) as well as other publications dealing with critical pedagogy, phenomenology, and the experiential worlds of young children. She currently teaches at the College of Art and Architecture.

\section{Max van Manen}

Professor of Education at the University of Alberta. He has taught school in the Netherlands and in Canada. Previously an assistant professor at the Ontario Institute for Studies in Education, he completed a a Ph.D. at the University of Alberta. He has published in the areas of social education, human science research methodology, curriculum theory, and pedagogical theorizing. A 1986 publication is The Tone of Teaching, a small book for parents and teachers. He is associated with various journals and is the founding editor of Phenomenology + Pedagogy. 